\title{
Clinical significance of Gremlin 1 in cervical cancer and its effects on cancer stem cell maintenance
}

\author{
MASAKAZU SATO, KEI KAWANA, ASAHA FUJIMOTO, MITSUYO YOSHIDA, HIROE NAKAMURA, \\ HARUKA NISHIDA, TOMOKO INOUE, AYUMI TAGUCHI, JURI TAKAHASHI, KATSUYUKI ADACHI, \\ KAZUNORI NAGASAKA, YOKO MATSUMOTO, OSAMU WADA-HIRAIKE, \\ KATSUTOSHI ODA, YUTAKA OSUGA and TOMOYUKI FUJII
}

Department of Obstetrics and Gynecology, Graduate School of Medicine, The University of Tokyo, Bunkyo-ku, Tokyo 1138655, Japan

Received August 6, 2015; Accepted September 14, 2015

DOI: $10.3892 /$ or.2015.4367

\begin{abstract}
Gremlin 1 is one of the bone morphogenetic protein (BMP) antagonists and is also related to differentiation in combination with BMPs and is associated with various types of diseases. Gremlin 1 is overexpressed in various types of human cancers and has been reported to play a role in cervical cancer oncogenesis. However, there is no report concerning the relationship between Gremlin 1 and cervical cancer stem cells (CSCs). The objective of the present study was to identify the clinical significance of Gremlin 1 in cervical cancer and its effects on CSC-like properties in vitro. Clinical samples were obtained. Gremlin 1 mRNA expression levels in the cervical cancer tissues were measured by RT-qPCR and assessed for correlation with their clinical prognosis [overall survival (OS), progression-free survival (PFS)] and with other prognostic factors. In vitro, cervical cancer, CaSki cells, exposed to Gremlin $1(1,000 \mathrm{ng} / \mathrm{ml})$ for $24 \mathrm{~h}$ were evaluated for expression of undifferentiated-cell markers (Nanog, Oct3/4, Sox 2 ) by RT-qPCR, the population of ALDH-positive cells by flow cytometry and sphere-forming ability on a ultra-low attachment culture dish. Cervical cancer tissues from 104 patients were collected. A high mRNA expression level of Gremlin 1 was an independent poor prognostic factor of PFS but not of OS. A high mRNA expression level of Gremlin 1 was correlated with bulky $(>4 \mathrm{~cm})$ tumors. The Nanog mRNA expression level was significantly increased in the CaSki cells exposed to Gremlin $1(\mathrm{P}=0.0008)$ but not Oct $3 / 4$ and Sox 2 mRNA expression levels. The population of ALDH-positive cells in the Gremlin 1-exposed cells was 1.41-fold higher compared with the control $(\mathrm{P}=0.0184)$. Sphere-forming ability
\end{abstract}

Correspondence to: Dr Kei Kawana, Department of Obstetrics and Gynecology, Graduate School of Medicine, The University of Tokyo, 7-3-1 Hongo, Bunkyo-ku, Tokyo 1138655, Japan

E-mail: kkawana-tky@umin.org

Key words: cancer stem cells, Gremlin 1, bone morphogenetic protein, cervical cancer, aldehyde dehydrogenase 1 was increased when 1,000 Gremlin 1-exposed cells were seeded $(\mathrm{P}=0.0379)$. In cervical cancer, it is suggested that Gremlin 1 may have a role in clinical recurrence and maintaining CSC-like properties.

\section{Introduction}

The cancer stem cell (CSC) theory states that only a small population of cells within a tumor is tumorigenic and has the ability for self-renewal (1). CSCs are thought to be related to tumor recurrence and treatment resistance; even though we treat non-CSCs by surgery or chemotherapy, relapse or metastasis may result if CSCs should resist (2). This theory was first suggested in leukemia, and many studies investigating CSCs are now performed in various types of solid tumors such as glioblastoma, colon cancer, breast cancer and prostate cancer (3-7). Undifferentiated-cell (normal stem cell) markers such as Nanog, OCT3/4 and SOX2 are known to be expressed in a small population of cancer cells (8-17). Increasing evidence suggests that tumor tissues are not homogeneous but heterogeneous supporting the CSC hypothesis.

Gremlin 1 is one of the bone morphogenetic protein (BMP) antagonists and especially antagonizes with BMP2, BMP4 and BMP7 $(18,19)$. BMPs are members of the transforming growth factor (TGF)- $\beta$ superfamily and play an essential role during development and differentiation while Gremlin 1 is also related to differentiation in combination with BMPs and its dysregulation results in developmental diseases (20-23). Gremlin 1 is overexpressed in various types of human cancers (24-26). Recently several studies have demonstrated that CSCs prevent the BMP differentiating effect by secreting Gremlin 1 in glioblastoma, suggesting that Gremlin 1 plays a role in maintenance of CSC properties $(27,28)$. In gynecological malignancies such as ovarian, endometrial and cervical cancers, various techniques to isolate cells with CSC-like properties have been reported. For instance, CD44- or CD133-positive cells are known to be more tumorigenic than negative ones in ovarian cancer $(29,30)$. Similar findings have been suggested for side population (SP) cells in endometrial cancer and ALDH1-positive cells in cervical cancer (31-36). Gremlin 1 is also reported to be expressed in cervical cancer 
compared to normal tissues of the cervix (37). A few studies have investigated the significance of BMPs in cervical cancer (38-40), however, there are no studies on the clinicopathological significance of Gremlin 1 in cervical cancer nor on the function of Gremlin 1 in CSC-like cells of cervical cancer.

Viewing the importance of Gremlin 1 in CSC maintenance and expression of Gremlin 1 in cervical cancer tissue, we hypothesized that Gremlin 1 may be correlated with the prognosis of cervical cancer through maintaining CSC properties. In the present study, we first demonstrated the clinicopathological significance of Gremlin 1 in stage I-II cervical cancer patients and the in vitro promoting effects of Gremlin 1 on CSC properties in cervical cancer cells.

\section{Materials and methods}

Patients. The present study was approved by the Institutional Ethics Committee, and written informed consent was obtained from each patient. Patients with a diagnosis of cervical cancer (stage I-II) who underwent primary surgery at the University of Tokyo Hospital from 2005 to 2014 were enrolled. A total of 104 samples were obtained.

RNA extraction and RT-quantitative PCR (RT-qPCR). Cervical cancer tissues (100-200 mg) were collected and snap frozen with liquid nitrogen and preserved at $-80^{\circ} \mathrm{C}$. Tissues were homogenized using MagNA Lyser Instrument (Roche Diagnostics, Mannheim, Germany) and total RNA was extracted with a Tissue Total RNA kit (Favorgen Biotech Corp., Ping-Tung, Taiwan) according to the manufacturer's protocols. First-strand cDNA was synthesized (reverse transcription reactions) from $1 \mu \mathrm{g}$ of total RNA using ReverTra Ace (Toyobo, Osaka, Japan). RT-qPCR was performed with SYBR-Green PCR Master Mix (Roche Diagnostics) according to the manufacturer's instructions. $\beta$-actin was used as a housekeeping gene, and the results are represented as foldchange relative to $\beta$-actin expression $\left(2^{-\Delta \Delta \mathrm{Ct}}\right)$. The sequences of the primer pairs used were as follows: Gremlin 1, forward, 5'-TCATCAACCGCTTCTGTTACGGC-3' and reverse, 5'-CAGAAGGAGCAGGACTGAAAGG-3'; Nanog, forward 5'-GCTGAGATGCCTCACACGGAG-3' and reverse 5'-TCTGTTTCTTGACCGGGACCTTGTC-3'; OCT3/4, forward 5'-TGGAGAAGGAGAAGCTGGAGCAAAA-3' and reverse 5'-GGCAGATGGTCGTTTGGCTGAATA-3'; SOX2, forward 5'-GGAAATGGGAGGGGTGCAAAAGAGG-3' and reverse 5'-TTGCGTGAGTGTGGATGGGATTGGTG-3'; $\beta$-actin, forward 5'-CTGGAACGGTGAAGGTGACA-3' and reverse 5'-AAGGGACT TCCTGTA ACA ACGCA-3'. Denaturation was performed at $95^{\circ} \mathrm{C}$ for $2 \mathrm{~min}$, followed by 35 cycles at $98^{\circ} \mathrm{C}$ for $10 \mathrm{sec}$, at $65^{\circ} \mathrm{C}$ for $10 \mathrm{sec}$ and at $68^{\circ} \mathrm{C}$ for 8 sec. Each experiment was performed in triplicate and repeated three times.

Cell culture. The human squamous cell carcinoma cell line CaSki (derived from a metastatic site; small intestine) was obtained from the American Type Culture Collection (ATCC, Manassas, VA, USA) and cultured in adherent conditions in Dulbecco's modified Eagle's medium (DMEM; Wako Pure Chemical Industries Ltd., Osaka, Japan) supple-
Table I. Characteristics of the cervical cancer patients.

\begin{tabular}{|c|c|c|}
\hline Features & Cases (n) & Percentage $(\%)$ \\
\hline Mean age (range) in years & \multicolumn{2}{|c|}{$44.0(22.9-75.1)$} \\
\hline \multicolumn{3}{|l|}{ FIGO stage } \\
\hline Stage I & 69 & 66 \\
\hline Stage II & 35 & 34 \\
\hline \multicolumn{3}{|l|}{ Histology } \\
\hline $\mathrm{SCC}$ & 59 & 56 \\
\hline Non-SCC & 45 & 44 \\
\hline \multicolumn{3}{|l|}{ Tumor size } \\
\hline$\leq 4 \mathrm{~cm}$ & 46 & 44 \\
\hline$>4 \mathrm{~cm}$ & 58 & 56 \\
\hline \multicolumn{3}{|l|}{ Pm invasion } \\
\hline Negative & 79 & 75 \\
\hline Positive & 25 & 25 \\
\hline \multicolumn{3}{|l|}{ Stromal invasion } \\
\hline$\leq 2 / 3$ & 48 & 46 \\
\hline$>2 / 3$ & 56 & 54 \\
\hline \multicolumn{3}{|l|}{ Margin } \\
\hline Negative & 98 & 94 \\
\hline Positive & 6 & 6 \\
\hline \multicolumn{3}{|l|}{ LVSI } \\
\hline Negative & 43 & 41 \\
\hline Positive & 61 & 59 \\
\hline \multicolumn{3}{|l|}{ LN metastasis } \\
\hline Negative & 73 & 70 \\
\hline Positive & 31 & 30 \\
\hline \multicolumn{3}{|l|}{ Recurrence } \\
\hline Negative & 84 & 81 \\
\hline Positive & 20 & 19 \\
\hline
\end{tabular}

SCC, squamous cell carcinoma; Pm, parametrium; LVSI, lymphovascular space involvement; LN, lymph node.

mented with $10 \%$ fetal bovine serum (FBS; Invitrogen Life Technologies, Carlsbad, CA, USA) and sub-cultured by $0.25 \%$ trypsin/EDTA (Wako Pure Chemical Industries Ltd.) detachment. For the sphere-forming assays, DMEM/F12 (Invitrogen Life Technologies) supplemented with $20 \mathrm{ng} / \mathrm{ml}$ human recombinant epidermal growth factor (EGF; Wako Pure Chemical Industries Ltd.), $10 \mathrm{ng} / \mathrm{ml}$ basic fibroblastic growth factor (bFGF; ReproCELL, Inc., Kanagawa, Japan) and $0.3 \%$ bovine serum albumin (BSA; Sigma-Aldrich Co., St. Louis, MO, USA) (sphere medium) was used. Each medium contained no antibiotics. All cells were grown and treated in a humidified atmosphere at $37^{\circ} \mathrm{C}$ and $5 \% \mathrm{CO}_{2}$. When $60-70 \%$ confluence was reached, the medium was replaced with DMEM containing $0.5 \% \mathrm{FBS}$ and 1,000 ng/ml human recombinant Gremlin 1 (R\&D Systems Inc., Minneapolis, MN, USA) or vehicle for another $24 \mathrm{~h}$ and total RNA was extracted.

Flow cytometry. The ALDH enzymatic activity of the cells was measured using the ALDEFLUOR kit (StemCell 
Table II. Predictive factors for overall survival (OS).

\begin{tabular}{|c|c|c|c|c|}
\hline \multirow[b]{2}{*}{ Features } & \multicolumn{2}{|c|}{ Univariate } & \multicolumn{2}{|c|}{ Multivariate } \\
\hline & Relative risk $(95 \% \mathrm{CI})$ & P-value & Relative risk $(95 \% \mathrm{CI})$ & $\mathrm{P}$-value \\
\hline Stage (II vs. I) & $2.91(0.60-16.07)$ & 0.1782 & $1.44(0.28-9.15)$ & 0.6624 \\
\hline Histology (NS vs. SCC) & $3.13(0.66-22.04)$ & 0.1508 & $4.11(0.86-29.21)$ & 0.0758 \\
\hline $\begin{array}{l}\text { Bulky }(>4 \mathrm{~cm}) \text { tumor } \\
\text { (positive vs. negative) }\end{array}$ & $5.14(0.86-97.49)$ & 0.0739 & $1.81(0.28-35.39)$ & 0.5679 \\
\hline $\begin{array}{l}\text { Pm invasion } \\
\text { (positive vs. negative) }\end{array}$ & $0.61(0.032-3.81)$ & 0.6404 & - & - \\
\hline $\begin{array}{l}\text { Stromal invasion } \\
(>2 / 3 \text { vs. } \leq 2 / 3)\end{array}$ & $1.34(0.27-7.41)$ & 0.7114 & - & - \\
\hline Margin (positive vs. negative) & $3.26(0.16-20.46)$ & 0.3458 & - & - \\
\hline LVSI (positive vs. negative) & $1.28 \mathrm{e}^{9}(2.23-\#)$ & $0.0064^{\mathrm{a}}$ & $1.04 \mathrm{e}^{9}(1.31-111)$ & $0.0064^{\mathrm{a}}$ \\
\hline $\begin{array}{l}\text { LN metastasis } \\
\text { (positive vs. negative) }\end{array}$ & $2.02(0.38-9.65)$ & 0.3796 & - & - \\
\hline Expression of Gremlin 1 & $0.39(0.017-1.54)$ & 0.3354 & - & - \\
\hline
\end{tabular}

LVSI was statistically significant to predict poor prognosis in the multivariate analysis. Factors showing a tendency of association with poor prognosis $(\mathrm{P}<0.25)$ in the univariate analysis were included in the multivariate model. Parametrium invasion and stromal invasion were excluded due to possible multicollinearity with bulky tumor. \#, the value was not available in the software. ${ }^{a} \mathrm{P}<0.05$. NS, non-squamous carcinoma; SCC, squamous cell carcinoma; Pm, parametrium; LVSI, lymphovascular space involvement; LN, lymph node; CI, confidence interval.

Technologies, Vancouver, BC, Canada) according to the manufacturer's protocol. CaSki cells $\left(1 \times 10^{6}\right.$ cells $)$ were suspended in ALDEFLUOR assay buffer containing ALDH substrate. The brightly fluorescent ALDH-positive cells were detected using FACSCalibur flow cytometer (BD Biosciences, San Jose, CA, USA). As a negative control, cells were stained under identical conditions after treatment with the specific ALDH inhibitor N,N-diethylaminobenzaldehyde (DEAB). For obtaining consistent results, the following conditions were applied; $2 \times 10^{5}$ cells were seeded onto a 6 -well multiplate dish in triplicate for $48 \mathrm{~h}$ and medium was switched to DMEM containing 3\% FBS and Gremlin $1(1,000 \mathrm{ng} / \mathrm{ml})$ or vehicle for another $24 \mathrm{~h}$ and flow cytometry was performed as described above. Each experiment was repeated three times.

Sphere-forming assay. CaSki cells were cultured under the conditions described for flow cytometry, and then the sphere-forming assay was performed. Dissociated single cells (1,000 cells) were seeded onto ultra-low attachment multi-plate (24-well) dish (Corning Inc., Corning, NY, USA) in quadruplicate and cultured in sphere medium for another 7 days. After that, spheroids larger than $100 \mu \mathrm{m}$ in diameter were counted, and the number of spheroids was compared between the Gremlin 1-exposed cells and the control (vehicle). Each experiment was repeated three times.

Statistical analysis. Known clinicopathological prognostic factors and expression of Gremlin $1 \mathrm{mRNA}$ were analyzed by univariate Cox proportional hazards regression models, and the relative risk (RR) with $95 \%$ confidence intervals (CIs) was evaluated. Logistic regression analysis was performed to investigate the relationship between Gremlin 1 mRNA expression level and recurrence. Using this result, receiver operating characteristic (ROC) curves were used to assess the criterion value. Kaplan-Meier curves were used to estimate the probability of OS and PFS, and the log-rank test was used to compare survival between the two groups (high Gremlin 1 mRNA or low Gremlin 1 mRNA levels). A $\chi^{2}$ test was used to evaluate the relationship between expression of Gremlin 1 and each clinicopathological factor. For the in vitro study, the Student's t-test was used to compare the data obtained for the controls. $\mathrm{P}<0.05$ was considered to indicate a statistically significant difference. $\mathrm{JMP}^{\circledR}$ (SAS Institute) was used for statistical analysis.

\section{Results}

Expression of Gremlin 1 in cervical cancer tissues is significantly correlated with progression-free survival (PFS) and recurrence. Characteristics of the 104 patients whose cancer tissues were collected are shown in Table I. Expression of Gremlin 1 mRNA was not a significant prognostic factor for overall survival (OS) in the univariate analysis (Table II) but was a prognostic factor for PFS in both univariate and multivariate analyses as well as histology (non-squamous carcinoma) (Table III). Expression of Gremlin 1 mRNA was also significantly correlated with recurrence in the logistic regression analysis. Cut-off value for high and low expression was set using ROC curves; high expression of Gremlin 1 mRNA, >0.20; low expression, $<0.20$ (Fig. 1). Kaplan-Meier curves for OS and PFS in patients with high and low Gremlin 1 mRNA expression are shown in Fig. 2. High expression of Gremlin 1 mRNA was a significant prognostic factor for PFS (log-rank test, $\mathrm{P}=0.0004)$. 
Table III. Predictive factors for progression-free survival (PFS).

Univariate

Multivariate

Features

Relative risk (95\% CI)

P-value

Relative risk (95\% CI)

P-value

Stage (II vs. I)

$3.30(1.36-8.43)$

$0.0082^{\mathrm{a}}$

$1.84(0.69-5.27)$

0.3247

Histology (NS vs. SCC)

2.57 (1.05-6.86)

$0.0379^{\mathrm{a}}$

$4.01(1.55-11.51)$

$0.0077^{\mathrm{a}}$

Bulky (>4 cm) tumor

$4.86(1.63-20.84)$

0.0030

2.85 (0.86-13.10)

0.1021

(positive vs. negative)

$\mathrm{Pm}$ invasion

$2.20(0.86-5.33)$

0.0959

(positive vs. negative)

Stromal invasion

$1.59(0.65-4.24)$

0.3108

(>2/3 vs. $\leq 2 / 3$ )

Margin (positive vs. negative)

$1.06(0.05-5.18)$

0.9491

LVSI (positive vs. negative)

$6.84(1.97-43.04)$

$0.0011^{\mathrm{a}}$

$2.37(0.97-5.79)$

0.0565

(positive vs. negative)

Expression of Gremlin 1 mRNA

$1.43(1.05-1.78)$

$0.0281^{\mathrm{a}}$

$1.41(1.01-1.78)$

$0.0036^{\mathrm{a}}$

Factors showing a significant association with poor prognosis $(\mathrm{P}<0.05)$ in the univariate analysis were included in the multivariate model. ${ }^{a} \mathrm{P}<0.05$. Histology and expression of Gremlin $1 \mathrm{mRNA}$ were statistically significant to predict poor prognosis in the multivariate analysis.NS, non-squamous carcinoma; SCC, squamous cell carcinoma; Pm, parametrium; LVSI, lymphovascular space involvement; LN, lymph node; CI, confidence interval.

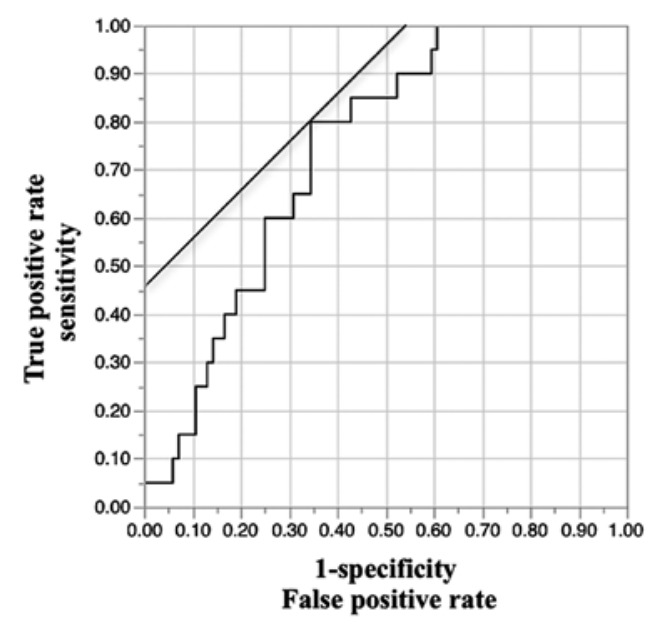

Figure 1. Receiver operating characteristic (ROC) curve. Expression of Gremlin 1 mRNA was significantly correlated with recurrence in the logistic regression analysis $(\mathrm{P}=0.032)$. Cut-off value for high and low expression of Gremlin 1 mRNA was set. High expression of Gremlin 1 mRNA $(>0.20)$ predicted clinical recurrence with a sensitivity/specificity of $0.80 / 0.66$. $\mathrm{x}$-axis, false-positive rate; $y$-axis, true-positive rate.

High expression of Gremlin 1 in cervical cancer tissues is significantly correlated with a bulky tumor. The correlations between expression of Gremlin 1 mRNA and each prognosis factor are listed in Table IV. Of note, high expression of Gremlin 1 mRNA was significantly correlated with a bulky $(>4 \mathrm{~cm})$ tumor ( $\chi^{2}$ test, $\left.\mathrm{P}=0.0494\right)$.

Exposure of CaSki cells to Gremlin 1 increases Nanog mRNA expression levels and the percentage of ALDH1-positive cells

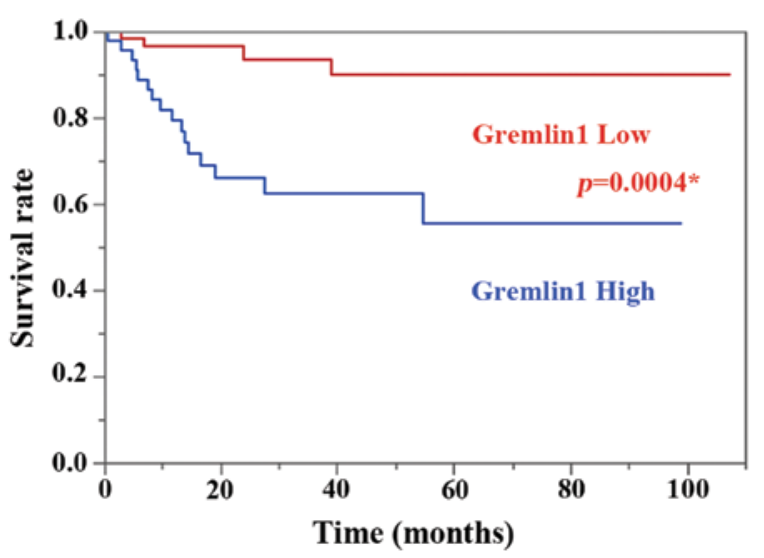

Figure 2. Kaplan-Meier curves of two patient groups (high Gremlin 1 mRNA or low Gremlin $1 \mathrm{mRNA}$ level). The group with a high Gremlin $1 \mathrm{mRNA}$ expression level had significantly poor prognosis of progression (the log-rank test. $\mathrm{P}=0.0004)$. Distinction of expression levels (high or low) was made using ROC curves; high expression of Gremlin 1 mRNA, $>0.20$; low expression, $<0.20$. $\mathrm{x}$-axis, time (months); $\mathrm{y}$-axis, survival rate.

in vitro. We then speculated whether the clinical significance of Gremlin 1 expression is attributed to CSC-like properties. We decided to use a CaSki cell in vitro model as CaSki cells are derived from a recurrent and metastatic site. Cancer stem cells are thought to share normal stem cell features and express undifferentiated-cell markers such as Nanog, Oct3/4 and Sox2. ALDH1-positive cells are reported to be a marker of cancer stem-like cells in various types of solid tumors including cervical cancer. After culturing CaSki cells for $48 \mathrm{~h}$, we exposed cells to Gremlin $1(1,000 \mathrm{ng} / \mathrm{ml})$ or vehicle control for $24 \mathrm{~h}$ and assessed these markers. Exposing CaSki cells to Gremlin 1 significantly 
A

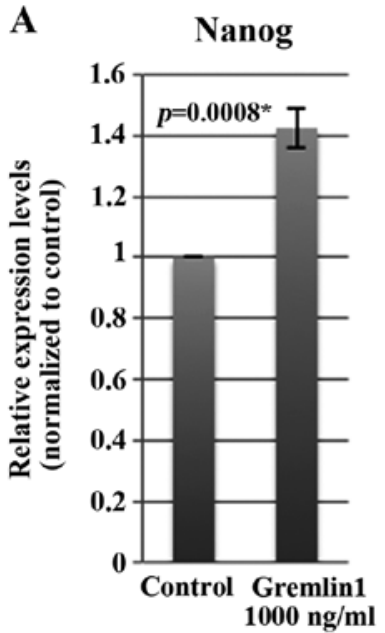

Oct3/4

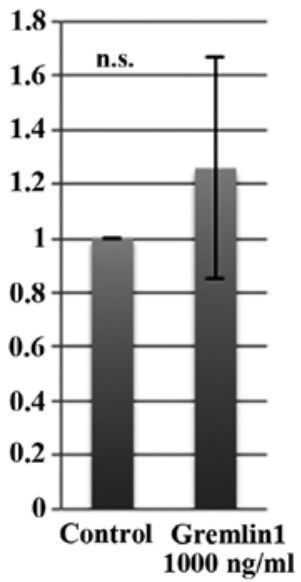

Sox2

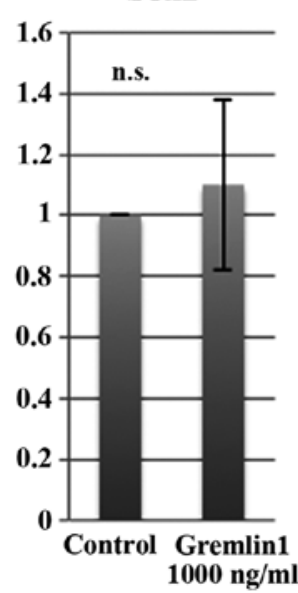

B

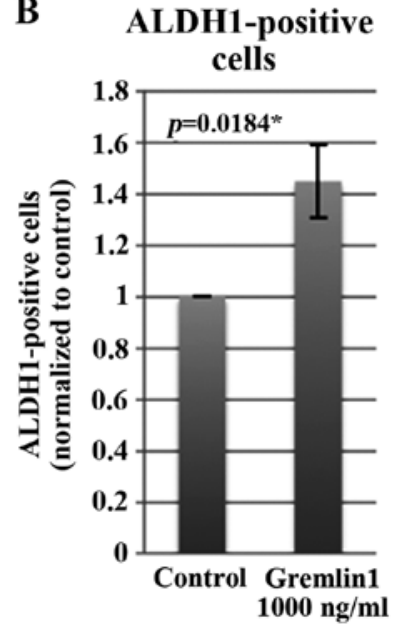

Figure 3. Effects of Gremlin 1 exposure on CSC-like properties of CaSki cells. (A) Undifferentiated-cell marker expression in Gremlin 1-exposed CaSki cells. Exposure of CaSki cells to Gremlin $1(1,000 \mathrm{ng} / \mathrm{ml})$ significantly increased the expression of Nanog mRNA but not Oct3/4 and Sox $2 \mathrm{mRNA}$ (t-test, $\mathrm{P}=0.0008)$. Experiments were performed in triplicate and repeated three times. The values shown represent the mean $\pm \mathrm{SD}$. $\mathrm{x}$-axis, control or Gremlin 1 group; $\mathrm{y}$-axis, relative expression levels (normalized to the control). (B) Population of ALDH1-positive cells in the Gremlin 1-exposed cells normalized to that of the control is shown. Exposure of CaSki cells to Gremlin $1(1,000 \mathrm{ng} / \mathrm{ml})$ significantly ( 1.41-fold) increased the population of ALDH1-positive cells compared to the vehicle control (t-test, $\mathrm{P}=0.0184)$. Experiments were performed in triplicate and repeated three times. The values shown represent the mean $\pm \mathrm{SD}$. $\mathrm{x}$-axis, control or Gremlin 1 group; y-axis, ALDH1-positive cells (normalized to control).

Table IV. Correlation between expression of Gremlin 1 mRNA (high or low) and each risk clinicopathological factor.

\begin{tabular}{|c|c|c|}
\hline Features & Relative risk (95\% CI) & P-value \\
\hline Stage (II vs. I) & $1.38(0.81-2.37)$ & 0.2325 \\
\hline Histology (NS vs. SCC) & $1.14(0.37-1.77)$ & 0.5415 \\
\hline $\begin{array}{l}\text { Bulky }(>4 \mathrm{~cm} \text { ) tumor } \\
\text { (positive vs. negative) }\end{array}$ & $1.40(1.001-1.971)$ & $0.0494^{\mathrm{a}}$ \\
\hline $\begin{array}{l}\text { Pm invasion } \\
\text { (positive vs. negative) }\end{array}$ & $1.96(0.97-3.95)$ & 0.0534 \\
\hline $\begin{array}{l}\text { Stromal invasion } \\
(>2 / 3 \text { vs. } \leq 2 / 3)\end{array}$ & $1.05(0.74-1.51)$ & 0.7600 \\
\hline $\begin{array}{l}\text { Margin } \\
\text { (positive vs. negative) }\end{array}$ & $2.62(0.50-13.68)$ & 0.2345 \\
\hline $\begin{array}{l}\text { LVSI } \\
\text { (positive vs. negative) }\end{array}$ & $1.04(0.75-1.43)$ & 0.8076 \\
\hline $\begin{array}{l}\text { LN metastasis } \\
\text { (positive vs. negative) }\end{array}$ & $1.59(0.88-2.87)$ & 0.0189 \\
\hline
\end{tabular}

Correlation between high Gremlin 1 mRNA expression and bulky tumor was significant $\left(\chi^{2}\right.$ test. $\left.\mathrm{P}=0.0494\right)$. ${ }^{\mathrm{P}} \mathrm{P}<0.05$. NS, non-squamous carcinoma; SCC, squamous cell carcinoma; Pm, parametrium; LVSI, lymphovascular space involvement; LN, lymph node; CI confidence interval.

increased the expression of Nanog mRNA but not Oct3/4 and Sox 2 mRNA (Fig. 3A). Likewise, exposing CaSki cells to Gremlin 1 significantly ( 1.41-fold) increased the population of ALDH1-positive cells compared to the control (Fig. 3B). These results were not obtained when the concentration of Gremlin 1 was reduced to $500 \mathrm{ng} / \mathrm{ml}$ (data not shown).
Exposing CaSki cells to Gremlin 1 increases sphere-forming ability. We then investigated the sphere-forming ability of Gremlin 1-exposed cells. Significantly more spheroids were formed when 1,000 cells of Gremlin 1-exposed cells were seeded compared to the control (Fig. 4A). A representative counted spheroid ( $>100 \mu \mathrm{m}$ in diameter) is shown in Fig. 4B.

\section{Discussion}

Here, we investigated the clinical significance of Gremlin 1 in cervical cancer and then investigated its effects on cancer cells in vitro.

The CSC theory states that only a small population of cells within a tumor is tumorigenic and has the ability for self-renewal. Increasing evidence suggests that tumor tissues are not homogeneous but heterogeneous and supports the CSC hypothesis in cervical cancer as well. Recently, Gremlin 1 has been suggested to be secreted by CSCs in glioblastoma and prevents CSCs from differentiating by its antagonistic effect on BMPs.

First, we showed that high expression of Gremlin 1 mRNA in cervical cancer tissues is a significant prognostic factor for PFS and clinical recurrence. High expression of Gremlin 1 mRNA was significantly correlated with a bulky $(>4 \mathrm{~cm})$ tumor, which is one of the most malignant features of cervical cancer. However, these findings should not be interpreted to conclude that cases of poor prognosis have a larger population of CSCs. Gremlin 1 was found to be secreted from stromal cancer-associated fibroblast (CAFs) in colon cancer and its expression was localized to invasion fronts (24-26). On the other hand, Gremlin 1 was found to be secreted by CSCs in glioblastoma and was thought to prevent CSCs from differentiating by antagonizing the effects ofBMPs $(27,28)$. Although there are no common views about the distribution pattern of Gremlin 1 expression in cervical cancer (37), we may safely say that a microenvironment of high expression of Gremlin 1 is favorable for CSC maintenance or invasion. 


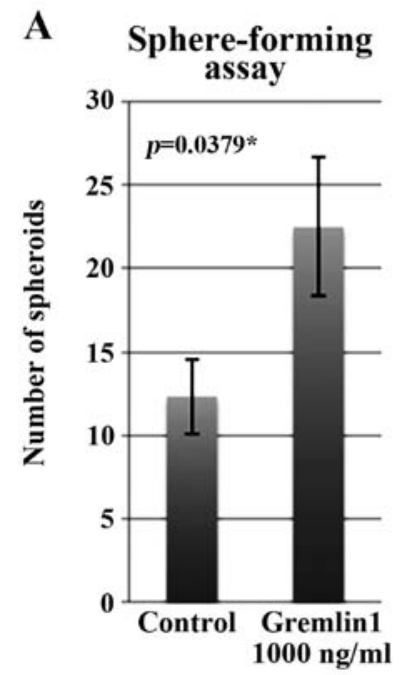

B

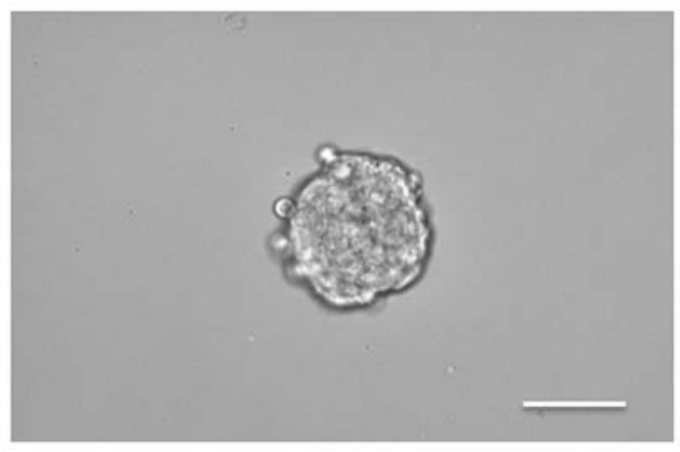

Figure 4. Sphere-forming ability of Gremlin 1-exposed CaSki cells. (A) After exposure to Gremlin $1(1,000 \mathrm{ng} / \mathrm{ml})$ for $24 \mathrm{~h}$, dissociated single cells $(1,000$ cells) were seeded onto an ultra-low attachment dish cultured in sphere medium for another 7 days. Significantly more spheroids were formed (t-test, $\mathrm{P}=0.0379$ ). Experiments were performed in quadruplicate and repeated three times. The values shown represent the mean $\pm \mathrm{SD}$. $\mathrm{x}$-axis, control or Gremlin 1 group; $y$-axis, number of spheroids. (B) A representative spheroid (>100 $\mu \mathrm{m}$ in diameter) is shown. Bar, $100 \mu \mathrm{m}$.

In an in vitro study, we revealed the effects of Gremlin 1 on CSC-like properties. The exposure of CaSki cells to Gremlin $1(1,000 \mathrm{ng} / \mathrm{ml})$ increased: i) Nanog mRNA expression levels (but not Oct $3 / 4$ and Sox 2 mRNA expression levels), ii) the population of ALDH-positive cells (1.41-fold higher compared with the control) and iii) sphere-forming ability when 1,000 Gremlin 1-exposed cells were seeded.

The effects of Gremlin 1 may have been obtained by preventing CSCs from differentiating or promoting non-CSCs to de-differentiate. We investigated changes in the population of ALDH1-positive CaSki cells in normal culture medium at each day after $48 \mathrm{~h}$ of seeding (Fig. 5). After $48 \mathrm{~h}$ of seeding, $>60 \%$ of adherent cells were ALDH1-positive and those percentages were reduced to $\sim 30 \%$ upon reaching confluency, which are compatible with previous reports that the ALDH1-positive population in CaSki cells are 20-30\% (32). In our experiments of Gremlin 1-exposure, the cells were $\sim 60-70 \%$ confluent after $48 \mathrm{~h}$ of seeding (when we exposed cells to Gremlin 1) and became $90-100 \%$ confluent when assessed after $72 \mathrm{~h}$ of seeding. Considering this fact and a previous report that ALDH1-negative cells do not become

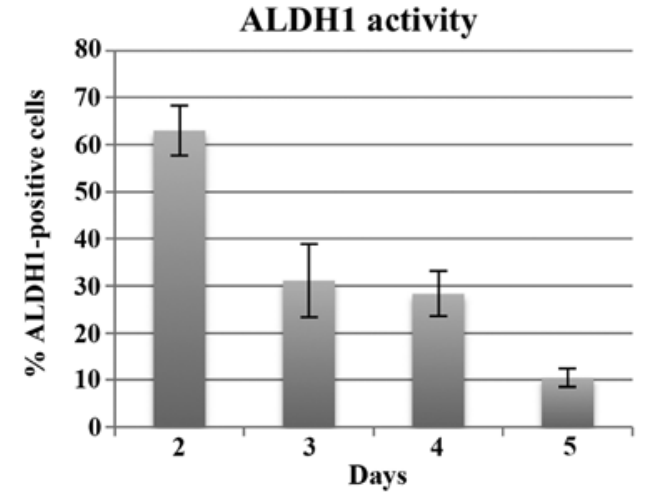

Figure 5. Changes in the population of ALDH1-positive CaSki cells in normal culture medium at each day. The percentage of ALDH1-positive CaSki cells at each day (day 2-5 at one day intervals after seeding) is shown. Cells $\left(2 \times 10^{5}\right)$ were seeded onto 6-well dish in duplicate. After $48 \mathrm{~h}$ of seeding (day 2), $>60 \%$ of adherent cells were ALDH1-positive and those percentages were reduced to $\sim 30 \%$ upon reaching confluency (day 3-4). Cells became over confluent at day 5. Experiments were repeated three times. The values shown represent the mean \pm SD. $x$-axis, day 2, 3, 4 or 5; y-axis, \% ALDH1-positive cells.

ALDH-positive (32), the effects of Gremlin 1 that we observed were achieved by preventing CSCs from differentiating to some extent resulting in increased sphere-forming ability.

Gremlin 1 specifically antagonizes BMP2, BMP4 and BMP7 function among the various members of BMPs (19). We performed the same experiments using BMP2, BMP4 and BMP7 (500 ng/ml). Only exposure of CaSki cells to BMP7 significantly reduced the expression of Nanog mRNA expression. However, the population of ALDH1-positive cells was not significantly different even between BMP7-exposed cells and the vehicle control (data not shown). This fact suggests that the BMP/Gremlin 1 axis is complex and we should not only consider high and low expression of BMPs or Gremlin 1 but the combination is important. Gremlin 1 is thought to have various effects on non-BMP signaling (41). We performed the same experiments using LDN-193189 [a small molecule inhibitor of BMP type I receptors ALK2 and ALK3 (42-44)] to confirm that our obtained results of Gremlin 1 were via BMP signaling. Exposure of CaSki cells to LDN-193189 increased the expression of Nanog mRNA in a dose-dependent manner and significantly high expression of Nanog mRNA was observed compared to the vehicle control when the concentration of LDN-193189 was $100 \mathrm{nM}$ (data not shown).

In conclusion, we demonstrated the clinical significance of Gremlin 1 in cervical cancer and insights into its effects on CSC-like properties in vitro were shown. In cervical cancer, it is suggested that Gremlin 1 may play a role in clinical recurrence and maintaining CSC-like properties.

\section{References}

1. Reya T, Morrison SJ, Clarke MF and Weissman IL: Stem cells, cancer, and cancer stem cells. Nature 414: 105-111, 2001.

2. Meacham CE and Morrison SJ: Tumour heterogeneity and cancer cell plasticity. Nature 501: 328-337, 2013.

3. Dick JE and JE D: Stem cell concepts renew cancer research. Blood 112: 4793-4807, 2008.

4. Chen X, Rycaj K, Liu X and Tang DG: New insights into prostate cancer stem cells. Cell Cycle 12: 579-586, 2013.

5. Skibinski A and Kuperwasser C: The origin of breast tumor heterogeneity. Oncogene 475: 1-8, 2015. 
6. Triscott J, Rose Pambid M and Dunn SE: Concise review: Bullseye: Targeting cancer stem cells to improve the treatment of gliomas by repurposing disulfiram. Stem Cells 33: 1042-1046, 2015.

7. Zeki SS, Graham TA and Wright NA: Stem cells and their implications for colorectal cancer. Nat Rev Gastroenterol Hepatol 8: 90-100, 2011

8. Liu CWLC, Li CH, Peng YJ, Cheng YW, Chen HW, Liao PL, Kang JJ and Yeng MH: Snail regulates Nanog status during the epithelial-mesenchymal transition via the Smad1/Akt/GSK3 $\beta$ signaling pathway in non-small-cell lung cancer. Oncotarget 5 : 3880-3894, 2014

9. Wang D, Lu P, Zhang H, Luo M, Zhang X, Wei X, Gao J, Zhao Z and Liu C: Oct-4 and Nanog promote the epithelial-mesenchymal transition of breast cancer stem cells and are associated with poor prognosis in breast cancer patients. Oncotarget 5: 10803-10815, 2014.

10. Iv Santaliz-Ruiz LE, Xie X, Old M, Teknos TN and Pan Q: Emerging role of nanog in tumorigenesis and cancer stem cells Int J Cancer 135: 2741-2748, 2014.

11. Kregel S, Szmulewitz RZ and Vander Griend DJ: The pluripotency factor Nanog is directly upregulated by the androgen receptor in prostate cancer cells. Prostate 74: 1530-1543, 2014.

12. Loh YH, Wu Q, Chew JL, Vega VB, Zhang W, Chen X, Bourque G, George J, Leong B, Liu J, et al: The Oct4 and Nanog transcription network regulates pluripotency in mouse embryonic stem cells. Nat Genet 38: 431-440, 2006.

13. Miyazawa K, Tanaka T, Nakai D, Morita N and Suzuki K Immunohistochemical expression of four different stem cell markers in prostate cancer: High expression of NANOG in conjunction with hypoxia-inducible factor-1 $\alpha$ expression is involved in prostate epithelial malignancy. Oncol Lett 8 : 985-992, 2014

14. Kumazawa S, Kajiyama H, Umezu T, Mizuno M, Suzuki S, Yamamoto E, Mitsui H, Sekiya R, Shibata K and Kikkawa F: Possible association between stem-like hallmark and radioresistance in human cervical carcinoma cells. J Obstet Gynaecol Res 40: 1389-1398, 2014

15. Liu XF, Yang WT, Xu R, Liu JT and Zheng PS: Cervical cancer cells with positive Sox 2 expression exhibit the properties of cancer stem cells. PLoS One 9: e87092, 2014.

16. Shen L, Huang X, Xie X, Su J, Yuan J and Chen X: High expression of SOX2 and OCT4 indicates radiation resistance and an independent negative prognosis in cervical squamous cell carcinoma. J Histochem Cytochem 62: 499-509, 2014

17. Wang L, Guo H, Lin C, Yang L and Wang X: Enrichment and characterization of cancer stem like cells from a cervical cancer cell line. Mol Med Rep 9: 2117-2123, 2014.

18. Khokha MK, Hsu D, Brunet LJ, Dionne MS and Harland RM: Gremlin is the BMP antagonist required for maintenance of Shh and Fgf signals during limb patterning. Nat Genet 34: 303-307, 2003.

19. Church RH, Krishnakumar A, Urbanek A, Geschwindner S, Meneely J, Bianchi A, Basta B, Monaghan S, Elliot C, Strömstedt $\mathrm{M}$, et al: Gremlin 1 preferentially binds to bone morphogenetic protein-2 (BMP-2) and BMP-4 over BMP-7. Biochem J 466: 55-68, 2015.

20. Wang RN, Green J, Wang Z, Deng Y, Qiao M, Peabody M, Zhang Q, Ye J, Yan Z, Denduluri S, et al: Bone morphogenetic protein (BMP) signaling in development and human diseases. Genes Dis 1: 87-105, 2014.

21. Ducy P and Karsenty G: The family of bone morphogenetic proteins. Kidney Int 57: 2207-2214, 2000.

22. Ciuclan L, Sheppard K, Dong L, Sutton D, Duggan N, Hussey M, Simmons J, Morrell NW, Jarai G, Edwards M, et al: Treatment with anti-gremlin 1 antibody ameliorates chronic hypoxia/SU5416-induced pulmonary arterial hypertension in mice. Am J Pathol 183: 1461-1473, 2013.

23. Worthley DL, Churchill M, Compton JT, Tailor Y, Rao M, Si Y, Levin D, Schwartz MG, Uygur A, Hayakawa Y, et al: Gremlin 1 identifies a skeletal stem cell with bone, cartilage, and reticular stromal potential. Cell 160: 269-284, 2015.

24. Karagiannis GS, Musrap N, Saraon P, Treacy A, Schaeffer DF Kirsch R, Riddell RH and Diamandis EP: Bone morphogenetic protein antagonist gremlin-1 regulates colon cancer progression. Biol Chem 396: 163-183, 2015.

25. Karagiannis GS, Treacy A, Messenger D, Grin A, Kirsch R, Riddell RH and Diamandis EP: Expression patterns of bone morphogenetic protein antagonists in colorectal cancer desmoplastic invasion fronts. Mol Oncol 8: 1240-1252, 2014.
26. Mulvihill MS, Kwon YW, Lee S, Fang LT, Choi H, Ray R, Kang HC, Mao JH, Jablons D and Kim IJ: Gremlin is overexpressed in lung adenocarcinoma and increases cell growth and proliferation in normal lung cells. PLoS One 7: e42264, 2012.

27. Seoane J: Gremlins sabotage the mechanisms of cancer stem cell differentiation. Cancer Cell 25: 716-717, 2014.

28. Yan K, Wu Q, Yan DH, Lee CH, Rahim N, Tritschler I, DeVecchio J, Kalady MF, Hjelmeland AB and Rich JN: Glioma cancer stem cells secrete Gremlin 1 to promote their maintenance within the tumor hierarchy. Genes Dev 28: 1085-1100, 2014.

29. Curley MD, Therrien VA, Cummings CL, Sergent PA, Koulouris CR, Friel AM, Roberts DJ, Seiden MV, Scadden DT, Rueda BR, et al: CD133 expression defines a tumor initiating cell population in primary human ovarian cancer. Stem Cells 27: 2875-2883, 2009.

30. Zhang S, Balch C, Chan MW, Lai HC, Matei D, Schilder JM, Yan PS, Huang TH and Nephew KP: Identification and characterization of ovarian cancer-initiating cells from primary human tumors. Cancer Res 68: 4311-4320, 2008.

31. Friel AM, Sergent PA, Patnaude C, Szotek PP, Oliva E, Scadden DT, Seiden MV, Foster R and Rueda BR: Functional analyses of the cancer stem cell-like properties of human endometrial tumor initiating cells. Cell Cycle 7: 242-249, 2008.

32. Liu SY and Zheng PS: High aldehyde dehydrogenase activity identifies cancer stem cells in human cervical cancer. Oncotarget 4 : 2462-2475, 2013.

33. Bortolomai I, Canevari S, Facetti I, De Cecco L, Castellano G, Zacchetti A, Alison MR and Miotti S: Tumor initiating cells: Development and critical characterization of a model derived from the A431 carcinoma cell line forming spheres in suspension. Cell Cycle 9: 1194-1206, 2010.

34. López J, Valdez-Morales FJ, Benítez-Bribiesca L, Cerbón M and Carrancá AG: Normal and cancer stem cells of the human female reproductive system. Reprod Biol Endocrinol 11: 53, 2013.

35. Maddox J, Shakya A, South S, Shelton D, Andersen JN, Chidester S, Kang J, Gligorich KM, Jones DA, Spangrude GJ, et al: Transcription factor Oct1 is a somatic and cancer stem cell determinant. PLoS Genet 8: e1003048, 2012.

36. Yao T, Wu Z, Liu Y, Rao Q and Lin Z: Aldehyde dehydrogenase 1 (ALDH1) positivity correlates with poor prognosis in cervical cancer. J Int Med Res 42: 1038-1042, 2014.

37. Namkoong H, Shin SM, Kim HK, Ha SA, Cho GW, Hur SY, Kim TE and Kim JW: The bone morphogenetic protein antagonist gremlin 1 is overexpressed in human cancers and interacts with YWHAH protein. BMC Cancer 6: 74, 2006.

38. Liu CY, Chao TK, Su PH, Lee HY, Shih YL, Su HY, Chu TY, Yu MH, Lin YW and Lai HC: Characterization of LMX-1A as a metastasis suppressor in cervical cancer. J Pathol 219: 222-231, 2009.

39. Tsuchida R, Osawa T, Wang F, Nishii R, Das B, Tsuchida S, Muramatsu M, Takahashi $\mathrm{T}$, Inoue $\mathrm{T}$, Wada $\mathrm{Y}$, et al: BMP4/Thrombospondin-1 loop paracrinically inhibits tumor angiogenesis and suppresses the growth of solid tumors. Oncogene 33: 3803-3811, 2014

40. Cassar L, Li H, Pinto AR, Nicholls C, Bayne S and Liu JP: Bone morphogenetic protein-7 inhibits telomerase activity, telomere maintenance, and cervical tumor growth. Cancer Res 68: 9157-9166, 2008

41. Mitola S, Ravelli C, Moroni E, Salvi V, Leali D, Ballmer-Hofer K, Zammataro L and Presta M: Gremlin is a novel agonist of the major proangiogenic receptor VEGFR2. Blood 116: 3677-3680, 2010.

42. Fotinos A, Nagarajan N, Martins AS, Fritz DT, Garsetti D, Lee AT, Hong CC and Rogers MB: Bone morphogenetic protein-focused strategies to induce cytotoxicity in lung cancer cells. Anticancer Res 34: 2095-2104, 2014.

43. Sanvitale CE, Kerr G, Chaikuad A, Ramel MC, Mohedas AH, Reichert S, Wang Y, Triffitt JT, Cuny GD, Yu PB, et al: A new class of small molecule inhibitor of BMP signaling. PLoS One 8: e62721, 2013.

44. Vogt J, Traynor R and Sapkota GP: The specificities of small molecule inhibitors of the TGFß and BMP pathways. Cell Signal 23: 1831-1842, 2011. 